\title{
THE ROLE OF BAITUL MAAL WA TAMWIL IN ALLEVIATING POVERTY IN CIANJUR REGENCY, WEST JAVA
}

\author{
Reksa Jayengsari $^{1}$, Uus Ahmad Husaeni ${ }^{2}$ \\ ${ }^{12}$ Department of Islamic Economic, Faculty of Islamic Economic and Business, Universitas \\ Suryakancana, Pasir Gede Raya Road, Bojongherang, Cianjur, West Java \\ uusahmad1@gmail.com
}

\begin{abstract}
This study aims to analyze the role of BMT in poverty alleviation in the Cianjur Regency. The research method used quantitative data collection using a questionnaire from 100 BMT members and data analysis techniques using multiple linear regression analysis. This article concludes that the poverty alleviation variable proxied by the income variable of BMT members is influenced by the real sector driving variable (providing financing) ( $\mathrm{t}$ count 1.747, sig 0.045 ), business education to the community ( $t$ count 2.324, sig 0.006), Fund utilization Baitul Maal ( $\mathrm{t}$ count 3,515, sig 0,000) and work motivation of members ( $\mathrm{t}$ count 2,599, sig $0,000)$. Meanwhile, the variable of micro business empowerment/business assistance did not significantly affect the income of BMT members ( $t$ count -0.621 , sig 0.536). Meanwhile, the $\mathrm{R}$ Square result is 0.643 , which means that BMT members' variable income is influenced by the real sector driving variables, business education, fund utilization, work motivation, and business empowerment by 64.3 percent. In comparison, the remaining 35.7 percent is influenced by other variables. Thus, the conclusion of this study is members' perceptions of the existence and role of BMT in increasing community income to reduce poverty levels due to activities that are social, educational, and increase work motivation.
\end{abstract}

Keywords: BMT, Poverty, Financing, Empowerment, Income.

\section{Introduction}

Physical and mental well-being is a condition coveted by humanity. The opposite of welfare is poverty, a condition that is wanted to be overcome in any development process. Poverty is seen as a condition of a person or group of people, men, and women whose fundamental rights are not appropriately fulfilled to lead and develop a dignified life. Thus, poverty is no longer understood only as an economic inability and the failure to fulfill fundamental rights and differences in treatment for a person or group of people living a life with dignity. Living in poverty does not only mean living in conditions of lack of clothing, food, and shelter. However, poverty also means low access to resources and productive assets to obtain life necessities, such as science, information, technology, and capital.
Several studies have discussed a lot about strategies to overcome poverty (Pattinama, 2009; Sahudiyono, 2009; Wardhani; Ritonga, 2011; Safi'i, 2011; (Susilawati P. S., 2019) Husaeni and Dewi, 2019).

Poverty is not only resolved by the government but also becomes a shared responsibility, be it the government, the private sector, professional institutions, universities, and the community itself. Suppose poverty is not watched out for, and substantial efforts and steps are taken to overcome it. In that case, it will have harmful consequences such as decreased quality of human resources, the emergence of social jealousy, unemployment, vulnerability, crime, and various other negative impacts. 
One of the efforts to reduce poverty is by breaking the poverty chain through group empowerment through microfinance institutions (Micro Finance Institutions/MFIs) (Sobana and Husaeni, 2019). Namely, a model for providing financial services for people who have businesses in the smallest sectors cannot access the banking world because of various limitations (Jayengsari and Husnaeni, 2020). In particular, MFIs are an effective way of helping and empowering communities and improving the family economy (Diodawati, 2004). Besides, MFIs are the best approach in empowering and developing micro-businesses to reduce poverty and increase income (Husaeni and Dewi, 2019). Much attention and effort in developing microfinance are primarily based on the motivation to accelerate poverty reduction efforts (Nasrulloh, 2020)(Amalia, 2009).

Poverty is a complicated problem in various regions in Indonesia, including in Cianjur Regency (Husaeni, 2017). To know a comprehensive picture of an area's condition, it can be seen from economic development, which is a series of efforts and policies aimed at increasing the community's standard of living, expanding employment opportunities, and equalizing community distribution income. If this can be done correctly, the welfare of the city can be realized. Until 2019, the level of development of community welfare in the Cianjur Regency has experienced fluctuating consequences. This is due to the economic crisis and natural disasters (the spread of Covid-19), which have had a significant impact on the level of people's welfare. The number of low-income families in the Cianjur Regency is relatively high, and from year to year, it has not decreased significantly. Thus, this article aims to analyze the role of BMT in poverty alleviation in Cianjur Regency.

\section{Method}

\section{Data and data sources}

This research was conducted in Cianjur Regency, West Java, which consisted of three BMT. The location selection was made because Cianjur district is one of the sections with a large population in the development of BMTs in West Java, which has provided a lot of financing to small communities to increase capital and meet their needs. The data analyzed in this study are the perception data of BMT members regarding BMT's role in increasing the income of their members through business financing activities, education to members, business assistance, utilization of Baitul Maal, and work motivation. In this study, a questionnaire was used in the form of a questionnaire given to 100 respondents who were members of the BMT in the Cianjur Regency to investigate these problems. After distributing questionnaires and obtaining the required data, data analysis is then carried out using statistical methods that discuss data collection techniques, presentation, processing or investigation, and interpretation of data.

\section{Instrument validity test}

According to Ferdinand (2006), a research instrument is said to be valid if it can reveal something that is its target, the subject of measurement. The validity test in this study used an external examination. The external validity test was tested using the Product Moment correlation formula from Carl Pearson. The Product Moment correlation formula is:

$$
\begin{aligned}
& \operatorname{rxy}=\frac{N \sum \sum \sum X Y-X Y}{\sqrt{ }}\{N X \Sigma \\
& \left.-\Sigma^{2}(X N Y)^{2}\right\}\left\{\Sigma-\Sigma^{2}(Y)^{2}\right\} \\
& \text { Informatio } \\
& \mathrm{n}: \\
& \mathrm{Rxy}=\text { Correlation coefficient } \\
& \mathrm{X}=\text { Value of each item } \\
& \mathrm{Y}=\text { total value of all items } \\
& \mathrm{N}=\text { Number of respondents or samples }
\end{aligned}
$$


Reksa Jayengsari, Uus Ahmad Husaeni: The Role Of Baitul Maal Wa Tamwil In Alleviating Poverty .

To test the validity, computer aids were used using SPSS 24.00 software. Suppose computer processing at the $5 \%$ significance level shows a result less than or equal to the $5 \%$ significance level. The item is declared valid, but if it is greater than $5 \%$, then the item is declared invalid.

\section{Instrument reliability test}

The purpose of this analysis is to determine the extent to which data measurements can give relatively no different results when re-measured on the same subject or show a match between what is measured (attribute) and the measuring instrument used. The reliability test used in this study was the Cronbach alpha method.

\section{Analysis Tools}

The general form of the multiple linear regression analysis models is used as an analytical tool for discussing how much influence the role of BMT has on poverty alleviation. Multiple linear regression analysis is an analytical technique that tries to explain the dependence of a dependent variable. The linear regression model used as an analytical tool is to use multiple regression equations, which are described as follows:

$\mathrm{Y}=\mathrm{E} 0+\mathrm{E} 1 \mathrm{X} 1+\mathrm{EX} 2+\mathrm{EX} 3+\mathrm{EX} 4+\mathrm{EX} 5+\mathrm{e}$ Where:

$\mathrm{Y}=$ Aspects of Income

$\mathrm{X} 1=$ drivers of the real sector (providing financing)

$\mathrm{X} 2$ = empowerment of micro-businesses / business assistance

$\mathrm{X} 3=$ Business education to the community

$\mathrm{X} 4=$ Utilization of baitul maal funds

X5 = Members' work motivation

$\mathrm{e}=$ bully error

\section{Discussions}

\section{Respondent Characteristics}

The characteristics of the respondents in this study are gender, age, education, and respondent status. The complete results are as follows. Parts of respondents based on the gender of the respondents are classified into male and female. The full results can be seen in Table 1.

Table: 1

Respondents Frequency Distribution Based on Gender

\begin{tabular}{clrl}
\hline $\begin{array}{l}\text { N } \\
\mathbf{0}\end{array}$ & Gender & Respondents & $\begin{array}{l}\text { Percent } \\
(\mathbf{\%})\end{array}$ \\
\hline 1 & Men & 41 & $41 \%$ \\
. & & & \\
2 & Women & 59 & $59 \%$ \\
. & & & \\
\hline
\end{tabular}

From the data analysis, the characteristics of respondents based on gender, the majority of respondents are women, that is, there are 59 people or $59 \%$ of the total respondents. Meanwhile, there were 41 men or $41 \%$ of the total respondents.

The characteristics of respondents based on the respondent's occupation are classified into traders, self-employed, farmers and laborers. The complete results can be seen in table 2 below.

Table: 2

\begin{tabular}{|c|c|c|c|}
\hline \multicolumn{4}{|c|}{$\begin{array}{l}\text { Respondents } \\
\text { Occupation }\end{array}$} \\
\hline $\begin{array}{l}\mathbf{N} \\
\mathbf{o}\end{array}$ & Job & Respondents & $\begin{array}{l}\text { Percent } \\
(\%)\end{array}$ \\
\hline 1. & Traders & 14 & $14 \%$ \\
\hline 3. & $\begin{array}{l}\text { entrepreneu } \\
\mathrm{r}\end{array}$ & 25 & $25 \%$ \\
\hline 4. & Farmer & 41 & $41 \%$ \\
\hline 5. & Labor & 20 & $20 \%$ \\
\hline
\end{tabular}


From the data analysis, the respondents' characteristics are based on occupation; the majority of respondents have a job as a farmer, namely 41 people or $41 \%$ of the total respondents. There were 14 merchant respondents or $14 \%$ of the total respondents. There are as many as 25 people (25\%) of the total respondents: self-employed and 20 workers $(20 \%)$ as laborers.

Characteristics of respondents based on the respondent's education are classified into Elementary School/equivalent, Junior High School/ equivalent, Senior High School/ equivalent, Diploma, and Bachelor's degree. The complete results can be seen in Table 3 .

Table: 3

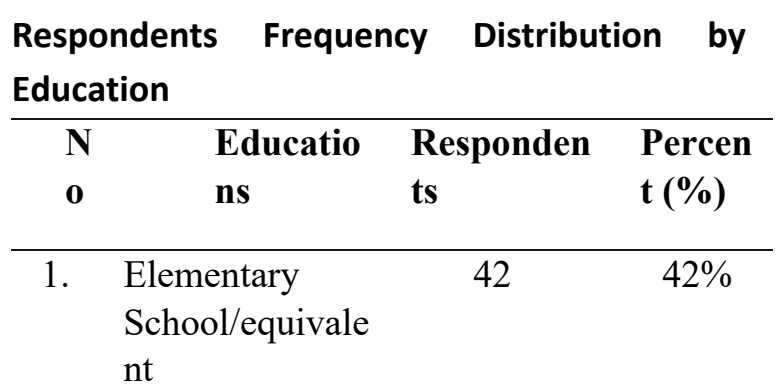

2. Junior High $31 \quad 31 \%$

School/

equivalent

3. Senior High $23 \quad 23 \%$
$\begin{aligned} & \text { School/ } \\ & \text { equivalent }\end{aligned}$

$\begin{array}{llll}\text { 4. } & \text { Diploma } & 3 & 3 \% \\ \text { 5. } & \text { Bachelor's } & 1 & 1 \%\end{array}$

From the data analysis, the characteristics of respondents based on education, the majority of respondents are elementary school graduates/equivalent, that is, there are 42 people or $42 \%$ of the total respondents. Mean while, 31 people graduated from Junior High School/ equivalent or $31 \%$ of the total respondents. There are three diploma graduates and one bachelor graduate.

Characteristics of respondents based on age are classified as less than 20 years, 20-29 years, 30-39 years, 40-49 years, 50-59 years, 60-69 years, and 70 years and over. Complete results can be seen in Table 4 .

Table: 4

Respondents' Frequency Distribution by Age

\begin{tabular}{lll}
\hline $\begin{array}{l}\text { N Age } \\
\text { o }\end{array}$ & Respondents & $\begin{array}{l}\text { Percent } \\
(\%)\end{array}$ \\
\hline 1. Under 20 Years & 0 & $0 \%$ \\
2. $20-29$ Years & 28 & $28 \%$ \\
3. $30-39$ Years & 33 & $33 \%$ \\
4. $40-49$ Years & 29 & $29 \%$ \\
5. $50-59$ Years & 6 & $6 \%$ \\
6. $60-69$ Years & 3 & $3 \%$ \\
7. 70 years and & 1 & $1 \%$ \\
\hline
\end{tabular}

From the data analysis, respondents' characteristics based on the age of the majority of respondents were between 30-39 years old. That is, there were 33 people or $33 \%$ of the total respondents. There were 28 respondents aged between 20-29 years or $28 \%$ of the total respondents. Respondents aged 40-49 years, there are as many as 29 people $(29 \%)$ of the total respondents. There are 6 respondents aged 50 59 years $(6 \%)$. And respondents aged 60 years and over were 4 people. 
Reksa Jayengsari, Uus Ahmad Husaeni: The Role Of Baitul Maal Wa Tamwil In Alleviating Poverty .

\section{Validity and Reliability Analysis}

\section{Validity test}

The validity test is used to test how carefully a test performs its measuring function or reflects the measured variable. The results of validity testing with the help of the SPSS program are aimed at knowing that each item of the question posed to the respondent is declared valid or not. The technique used in this validity test is the Pearson Correlation technique. The article is declared valid if the correlation $(r)$ is positive and significant. The results of the validity test are summarized in Table 5.

Table: 5

Results of Testing the Validity of the Real Economic Sector Driving Variables

\begin{tabular}{llll}
\hline \multirow{2}{*}{ Variable } & $\begin{array}{r}\text { Pearson } \\
\text { Correlatio }\end{array}$ & $\begin{array}{l}\text { r- } \\
\text { table }\end{array}$ & Conclusio \\
& ns & &
\end{tabular}

\begin{tabular}{llll}
\hline Drivers of & 0,581 & 0,36 & Valid \\
the Real & & 1 & \\
Economic & & & \\
Sector 1 & & &
\end{tabular}

$\begin{array}{llll}\text { Drivers of } & 0,518 & 0,36 & \text { Valid } \\ \text { the Real } & & 1 & \\ \text { Economic } & & & \\ \text { Sector } 2 & & \end{array}$

$\begin{array}{llll}\text { Drivers of } & 0,678 & 0,36 & \text { Valid } \\ \text { the Real } & & 1 & \\ \text { Economic } & & & \end{array}$

Sector 3

$\begin{array}{lccc}\begin{array}{l}\text { Drivers of } \\ \text { the Real }\end{array} & 0,573 & 0,36 & \text { Valid } \\ \begin{array}{l}\text { Economic } \\ \text { Sector } 4\end{array} & & 1 & \\ \begin{array}{l}\text { Drivers of } \\ \text { the Real }\end{array} & 0,753 & 0,36 & \text { Valid } \\ & & 1 & \end{array}$

Economic

Sector 5

$\begin{array}{llll}\begin{array}{l}\text { Drivers of } \\ \text { the Real }\end{array} & 0,681 & 0,36 & \text { Valid } \\ \begin{array}{l}\text { Economic } \\ \text { Sector } 6\end{array} & & 1 & \\ & & & \\ \begin{array}{l}\text { Drivers of } \\ \text { the Real }\end{array} & 0,706 & 0,36 & \text { Valid } \\ \begin{array}{l}\text { Economic } \\ \text { Sector } 7\end{array} & & 1 & \\ \begin{array}{l}\text { Drivers of } \\ \text { the Real }\end{array} & 0,645 & 0,36 & \text { Valid } \\ \begin{array}{l}\text { Economic } \\ \text { Sector } 8\end{array} & & 1 & \\ & & & \\ \begin{array}{l}\text { Drivers of } \\ \text { the Real }\end{array} & 0,474 & 0,36 & \text { Valid } \\ \text { Economic } & & 1 & \\ \text { Sector } 9 & & & \end{array}$

From testing the validity of the variables driving the real economic sector, it is proven that all items are valid because the value of $r$ count is more significant than the $r$ table (0.361). Thus all items can be used for further data collection using the real economic sector driving variables.

Table: 6

Results of Testing the Validity of Micro Business Empowerment

\begin{tabular}{|c|c|c|c|}
\hline Variable & $\begin{array}{l}\text { Pearson } \\
\text { Correlatio } \\
\text { ns }\end{array}$ & $\begin{array}{l}r- \\
\text { tabl } \\
\mathrm{e}\end{array}$ & $\begin{array}{l}\text { Conclusio } \\
\mathrm{ns}\end{array}$ \\
\hline $\begin{array}{l}\text { Micro Business } \\
\text { Assistance } 1\end{array}$ & 0,666 & $\begin{array}{l}0,3 \\
61\end{array}$ & Valid \\
\hline $\begin{array}{l}\text { Micro Business } \\
\text { Assistance } 2\end{array}$ & 0,705 & $\begin{array}{l}0,3 \\
61\end{array}$ & Valid \\
\hline $\begin{array}{l}\text { Micro Business } \\
\text { Assistance } 3\end{array}$ & 0,705 & $\begin{array}{l}0,3 \\
61\end{array}$ & Valid \\
\hline $\begin{array}{l}\text { Micro Business } \\
\text { Assistance } 4\end{array}$ & 0,797 & $\begin{array}{l}0,3 \\
61\end{array}$ & Valid \\
\hline
\end{tabular}




\begin{abstract}
Micro Business
Assistance 5

$0,646 \quad 0,3 \quad$ Valid 61

From the summary of the results of the validity test above, it can be seen that all items are valid because the $r$ count value is greater than the $r$ table (0.361), thus for further research, all item items can be used to retrieve data on micro-business mentoring variables.
\end{abstract}

From testing the validity of the business education variable, it is proven that all items -are valid because the $r$ count value is more significant than the $r$ table $(0.361)$, thus for

Table: 7

Results of Testing the Validity of Business Education Variables

\begin{tabular}{lccl}
\hline Variable & $\begin{array}{l}\text { Pearson } \\
\text { Correlations }\end{array}$ & $\begin{array}{l}\mathrm{r}- \\
\text { table }\end{array}$ & $\begin{array}{l}\text { Conclusio } \\
\text { ns }\end{array}$ \\
\hline $\begin{array}{l}\text { Business } \\
\text { Education }\end{array}$ & 0,71 & 0,3 & Valid \\
1 & 0 & 61 & \\
Business & 0,601 & 0,36 & Valid \\
Education & & 1 & \\
2 & & & \\
Business & 0,71 & 0,3 & Valid \\
$\begin{array}{l}\text { Education } \\
3\end{array}$ & 5 & 61 & \\
Business & & & \\
Education & 0,59 & 0,3 & Valid \\
4 & 1 & 61 & \\
Business & & & \\
Education & 0,58 & 0,3 & Valid \\
5 & 8 & 61 & \\
Business & & & \\
Education & 0,64 & 0,3 & Valid \\
6 & 7 & 61 & \\
\hline & & & \\
\hline
\end{tabular}
further research, all item items can be used to collect data on business education variables.

Table: 8

Results of Testing the Validity of Baitul Maal Funds Utilization Variables

\begin{tabular}{llll}
\hline & \multicolumn{2}{c}{ Pearso } & $\mathrm{r}-$ \\
Variable & $\mathrm{n}$ & tabl & Conclusi \\
& Correlati & $\mathrm{e}$ & ons \\
& ons & &
\end{tabular}

\begin{tabular}{lccc}
\hline $\begin{array}{l}\text { Use of Baitul } \\
\text { Maal Funds 1 }\end{array}$ & 0,688 & 0,3 & Valid \\
Use of Baitul & 0,806 & 0,3 & Valid \\
Maal Funds 2 & & 61 & \\
& & & \\
Use of Baitul & 0,850 & 0,3 & Valid \\
Maal Funds 3 & & 61 & \\
Use of Baitul & 0,714 & 0,3 & Valid \\
Maal Funds 4 & & 61 & \\
& & &
\end{tabular}

From testing the validity of the variable use of Baitul Maal funds, it is proven that all items are valid because the $r$ count value is more significant than $r$ table (0.361), thus; for further research, all item items can be used to collect data regarding the variable use of Baitul Maal funds.

Table: 9

Results of Testing the Validity of Member Work Motivation Variables

\begin{tabular}{llll}
\hline Variable & $\begin{array}{l}\text { Pearson } \\
\text { Correlations }\end{array}$ & $\begin{array}{l}\mathrm{r}- \\
\text { tabl } \\
\mathrm{e}\end{array}$ & $\begin{array}{l}\text { Conclusi } \\
\text { ons }\end{array}$ \\
\hline Work & 0,77 & 0,3 & Valid \\
Motivation & 7 & 61 &
\end{tabular}


Reksa Jayengsari, Uus Ahmad Husaeni: The Role Of Baitul Maal Wa Tamwil In Alleviating Poverty .

\begin{tabular}{|c|c|c|c|}
\hline \multicolumn{4}{|l|}{$\begin{array}{l}\text { of Members } \\
1\end{array}$} \\
\hline Work & 0,57 & 0,3 & Valid \\
\hline $\begin{array}{l}\text { Motivation } \\
\text { of Members }\end{array}$ & 3 & 61 & \\
\hline 2 & & & \\
\hline Work & 0,72 & 0,3 & Valid \\
\hline $\begin{array}{l}\text { Motivation } \\
\text { of Members }\end{array}$ & 7 & 61 & \\
\hline 3 & & & \\
\hline Work & 0,87 & 0,3 & Valid \\
\hline $\begin{array}{l}\text { Motivation } \\
\text { of Members }\end{array}$ & 8 & 61 & \\
\hline 4 & & & \\
\hline Work & 0,83 & 0,3 & Valid \\
\hline $\begin{array}{l}\text { Motivation } \\
\text { of Members }\end{array}$ & 6 & 61 & \\
\hline
\end{tabular}

From testing the validity of the member work motivation variable, it is evident that all items are valid because the value of $r$ count is more significant than the $r$ table (0.361).

Table: 10

Results of Testing the Validity of Income Aspects Variables

\begin{tabular}{llll}
\hline Variable & $\begin{array}{l}\text { Pearson } \\
\text { Correlations }\end{array}$ & $\begin{array}{l}\text { r- } \\
\text { table }\end{array}$ & Conclusio \\
& & &
\end{tabular}

\begin{tabular}{llll}
\hline Income & 0,503 & 0,36 & Valid \\
Aspects 1 & & 1 & \\
Income & 0,712 & 0,36 & Valid \\
Aspects 2 & & 1 & \\
Income & 0,507 & 0,36 & Valid \\
Aspects 3 & & 1 & \\
Income & 0,724 & 0,36 & Valid \\
Aspects 4 & & 1 &
\end{tabular}


coefficient is greater than the critical value of 0.361 ; it can be concluded that the questions regarding using Baitul Maal funds are reliable.

The alpha coefficient on the member work motivation variable is 0.769 . This variable can be declared reliable because the alpha coefficient is greater than the critical value, equal to 0.361 . It can be concluded that the questions regarding the work motivation of members are reliable.

For the income aspect variable, the alpha coefficient is 0.620 . This variable can be declared reliable because the alpha coefficient is greater than the critical value, which is 0.361 . it can be concluded that the items on the income aspect are reliable questions. From the results of the reliability analysis above, it can be interpreted that the comprehensive questionnaire used in this study has been declared reliable or dependable.

\section{Analysis of the Role of BMT on Income Levels}

The results of multiple linear regression analyses are summarized in Table 11.

Table: 11

Results of Multiple Linear Regression Analysis for Income Aspects

\begin{tabular}{lllll}
\hline Variable & $\begin{array}{l}\text { Regressio } \\
\mathrm{n} \\
\text { Coefficie } \\
\mathrm{nt}\end{array}$ & $\begin{array}{l}\mathrm{t} \\
\text { cou } \\
\mathrm{nt}\end{array}$ & $\begin{array}{l}\text { Probability } \\
\text { Information }\end{array}$ \\
\hline Real & 0,139 & 1,74 & 0,0 & Significa \\
Economic & & 7 & 45 & $\mathrm{nt}$ \\
Sector & & & & \\
Drivers & & & & \\
(X1) & & & & \\
\end{tabular}

\begin{tabular}{|c|c|c|c|c|}
\hline $\begin{array}{l}\text { Micro } \\
\text { Business } \\
\text { Assistanc } \\
\text { e (X2) }\end{array}$ & $-0,060$ & $\begin{array}{l}- \\
0,62 \\
1\end{array}$ & $\begin{array}{l}0,5 \\
36\end{array}$ & $\begin{array}{l}\text { No } \\
\text { Significa } \\
\text { nt }\end{array}$ \\
\hline $\begin{array}{l}\text { Business } \\
\text { Education } \\
\text { to the } \\
\text { Communi } \\
\text { ty (X3) }\end{array}$ & 0,197 & $\begin{array}{l}2,32 \\
4\end{array}$ & $\begin{array}{l}0,0 \\
06\end{array}$ & $\begin{array}{l}\text { Significa } \\
\mathrm{nt}\end{array}$ \\
\hline $\begin{array}{l}\text { Utilizatio } \\
\mathrm{n} \text { of } \\
\text { Baitul } \\
\text { Maal } \\
\text { Funds } \\
\text { (X4) }\end{array}$ & 0,423 & $\begin{array}{l}3,51 \\
5\end{array}$ & $\begin{array}{l}0,0 \\
00\end{array}$ & $\begin{array}{l}\text { Significa } \\
\text { nt }\end{array}$ \\
\hline $\begin{array}{l}\text { Member } \\
\text { Work } \\
\text { Motivatio } \\
\mathrm{n} \text { (X5) }\end{array}$ & 0,322 & $\begin{array}{l}2,59 \\
9\end{array}$ & $\begin{array}{l}0,0 \\
00\end{array}$ & $\begin{array}{l}\text { Significa } \\
\mathrm{nt}\end{array}$ \\
\hline Constant & 5,385 & & & \\
\hline R Square & & & &, 643 \\
\hline $\begin{array}{l}\text { Multiple } \\
\text { R }\end{array}$ & & & &, 765 \\
\hline F-count & & & & 2,943 \\
\hline $\begin{array}{l}\text { Probabilit } \\
\text { y }\end{array}$ & & & &, 000 \\
\hline $\begin{array}{l}\text { Durbin } \\
\text { Watson }\end{array}$ & & & & ,720 \\
\hline
\end{tabular}

The regression results have varied effects on the five variables. The erratic driving the real economic sector has a regression coefficient of 0.139 with a statistical probability of 0.045 . Based on individual statistical tests, according to members' perceptions, this variable affects the increase in income of BMT members in the Cianjur Regency. This means that BMT members think that BMT's role in increasing members' income through main activities in the form of business financing is successful. 
The micro-business facilitation factor is also a variable that does not affect the increase in BMT members' income in the Cianjur Regency. This variable has a regression coefficient of 0.060 . This means that if the members have the perception that micro-business assistance has not had an impact on increasing the income of BMT members in the Cianjur Regency.

Based on the regression analysis, the three other variables, namely the business education factor for members, the use of baitul maal funds, and the provision of motivation to work for members, have a significant role in increasing members' income. The community's business education factor is a variable that affects the increase in revenue of BMT members with a regression coefficient of 0.197 . This means that members have a perception that BMT can increase their income from educational activities carried out to them. Baitul Maal fund utilization factor is a variable that affects the increase in member income with a coefficient of 0.423. This shows that BMT social activities also have a positive role in increasing members' income. The member work motivation factor is a variable that affects the increase in member income with a regression coefficient of 0.322 . This variable has a decisive role in increasing member income. From these results, it can be implicated that the members' perceptions of the existence and function of BMTs in increasing community income in the context of poverty alleviation are more due to social, educational, and work motivation activities.

The concept of BMT in Indonesia has been rolling for more than a decade. This concept has had many pieces of evidence to reduce poverty. This institution's role in reducing poverty is very strategic, considering that banking institutions have not been able to touch the poor. Their access to banking is minimal, almost nonexistent. They also have no collateral and are not very good at making proposals.
BMT's strategic role in reducing poverty can be seen from the economic activities of BMTs that have social activities (Baitul Maal) and business activities (at-Tamwil). BMT's socio-economic activities are carried out with the zakat movement, infaq sadaqah, and waqaf. This is an advantage of BMT in reducing poverty. This BMT social activity can be called an effort to protect or social security that can significantly maintain the poor's development process. This social protection guarantees the distribution of a sense of welfare from people who do not have to people who have.

This is where BMT acts as an agent of asset distribution (agent distribution of assets from those who have to those who do not have it) capable of empowering the ummah economy (Faizah and Husaeni, 2019). This social function of BMT, at the same time, will be able to create a harmonious relationship between the two different classes. Meanwhile, for business activities, BMT provides financing to people who need business capital and serves people who want to deposit their funds with BMT with the Islamic concept. This, of course, will be able to provide loan assistance to people who need it.

These two virtues make BMT the most suitable institution in overcoming the poverty problems experienced by most Indonesian people (especially in Cianjur Regency). The two sides of fund management (Baitul Maal and Baitul Tamwil) should go hand in hand. If one does not exist, then the concept becomes lame and not optimal in achieving its goals. Such a scheme will later become a symbiotic mutualism in contributing to empowering the community, which can reduce poverty in Indonesia, especially in Bantul Regency. However, this will not materialize appropriately if it is not balanced with support from various aspects, be it the community, government, and BMT itself in realizing these big goals. 
Besides, BMT must improve the performance of all institution elements, both those related to services, products, promotion, and institutional health (BMT) themselves so that the public can trust BMT as one of the Islamic financial institutions to be reckoned with. What is even more critical is that BMTs must carry out their activities following the principles of Sharia, considering that BMT is an institution based on Sharia. If a BMT business or move follows Sharia, it is not tricky for BMT to help people get out of poverty. To increase the effectiveness of BMT's role in the Cianjur Regency it can be done by growing activities through education, utilization of Baitul Maal, and increasing work motivation of members. The results of this study are in line with previous studies conducted by Pattinama, 2009; Sahudiyono, 2009; Ritonga, 2011; Safi'i, 2011; Husaeni and Dewi, 2019; Sobana and Husaeni, 2019; and Jayengsari and Husnaeni, 2020.

\section{Conclusion}

Based on the analysis, the variables of business education, utilization of Baitul Maal funds, and motivating to work for members have a significant role in increasing members' income. The factor of the use of Baitul Maal funds is a variable that affects the increase in member income. The work motivation factor of members is also a variable that affects the rise in member income. This variable has an influential role in increasing member income. From these results, it can be implicated that the members' perceptions of the existence and function of BMTs in increasing community income in the context of reducing poverty levels are mainly due to social, educational, and work motivation activities.

\section{Reference}

Al-Qubbani, M. Bahauddin. 1999. "Miskin dan Kaya dalam Pandangan Al-Qur'an", terj. Abdul Hayyie al-Kattani dkk, Cet. ke-1, Gema Insani Press: Jakarta.
Amalia, Euis. 2009. "Keadilan Distributif dalam Ekonomi Islam; Penguatan Peran LKM dan UKM di Indonesia", ed. ke-I, PT Rajawali Pers: Jakarta.

Diodawati, Agus Nita. 2004. "Pemberdayaan pengusaha kecil di Lembaga Keuangan Syari'ah-BMT Assa'adah Malang". Skripsi tidak dipublikasikan, Fakultas Ekonomi Universitas Islam Negeri Malang.

Faizah, S.I. and Husaeni, U.A. 2019. Economic Empowerment for Poor Women Using Grameen Bank Model in Indonesia. KnE Social Sciences, 3(13): 880-913.

Falihah, Eti Ihda. 2007. "Peran BMT dalam Pemberdayaan Usaha Mikro (Studi Kasus di Koperasi BMT-MMU Kraton Sidogiri Pasuruan)". Skripsi tidak dipublikasikan, Fakultas Ekonomi Uneversitas Islam Negeri Malang.

Ferdinand, Agusty. 2006. Metode Penelitian Manajemen, Badan Penerbit Universitas Diponogoro, Semarang.

Husaeni, U.A. 2017. Potensi Ekonomi Desa Menuju Desa Mandiri (Studi di Desa Sukamanah Kecamatan Karangtengah Kabupaten Cianjur). Journal of Empowerment. 1(1): 112.

Husaeni, U.A. dan T.K Dewi. 2019. Pengaruh Pembiayaan Mikro Syariah Terhadap Tingkat Perkembangan Usaha Mikro Kecil Menengah (UMKM) pada Anggota BMT di Jawa Barat. BJRM Bongaya Journal for Research in Management. 2(1): 48-56.

Husaeni, U.A. and T.K Dew. 2019. The Dynamics of the Development Of Baitul Maal Wa Tamwil In Indonesia With The Swot Analysis Approach International Journal Of Scientific \& Technology Research. 8(8): 1678-1685.

Jayengsari, RA. and UA Husnaeni. 2020. Management of Financial Inclusion in Islamic Banking: Evidence from 
Reksa Jayengsari, Uus Ahmad Husaeni: The Role Of Baitul Maal Wa Tamwil In Alleviating Poverty .

Indonesia. Agregat: Jurnal Ekonomi dan Bisnis. 4(1): 44-58.

Muttaqien, Dadan. 2010. "Persepsi Nasabah Terhadap Penerapan Prinsip Syari'ah Dalam Operasional Lembaga Keuangan Mikro Syari'ah (Studi Kasus Nasabah BMT Haniva, Pleret, Bantul, Yogyakarta)", Laporan Penelitian DPPM UII Yogyakarta.

Nasrulloh, A. A. (2020). Pengembalian Fungsi Baitul Mal Wa Tamwil Melalui Strategi Penyelesaian Masalah Rentenir Di Tasikmalaya. Amwaluna: Jurnal Ekonomi dan Keuangan Syariah, 4(1), 75-95.

Pattinama, Marcus J. 2009. "Pengetasan Kemiskinan Dengan Kearifan Lokal (Studi Kasus di Pulau Buru-Maluku dan Surade-Jawa Barat)", Jurnal Makara Sosial Humaniora, Vol. 13, No. 1 Juli, hlm. 1-12.

Qardawi, Yusuf. 2007. Hukum Zakat, alih bahasa Didin Hafidhuddin dkk, Cet. ke10, Litera Antar Nusa: Bogor.

Sahudiyono. 2009. "Memberdayakan Masyarakat Pesisir dengan Pendekatan Program Pemberdayaan Ekonomi Masyarakat Pesisir (PEMP)", Jurnal Riset Daerah BAPEDA Bantul, Vol. VII, No. 3, Desember 2009, hlm. 11691189.

Situmorang, James. 2007. "Kaji Tindak Peningkatan Peran Koperasi dan UKM sebaga Lembaga Keuangan Alternatif", Jurnal Infokop, Vol. 2, Juli hlm. 24-35.

Ritonga, Hamonangan. 2011.'Pemantauan Kemiskinan Untuk Program Penanggulangan Kemiskinan Di Indonesia”, Rabu 14 Desember 2011, http://yapenwaropenkab.bps.go.id/.

Safi'i. 2011. “Ampih Kemiskinan; Model Kebijakan Penuntasan Kemiskinan dalam Perspektif Teori dan Praktik, Cet. ke-1, Averroes Press: Malang.
Shihab, Muhammad Quraish. 2012. Wawasan Al-Qur'an Tafsir Maudhu'i atas Pelbagai Persoalan Umat, Sabtu 31 April, http://wordpress.com.

Sobana, D.H. and U.A Husaeni. 2019. Economic Empowerment of Poor Women With Grameen Bank Patterns on Baitul Mal Wa Tamwil Ibadurrahman. International Journal of Islamic Economics and Finance Studies (IJISEF). 5(1): 40-59.

Susilawati, P. S., Ibrahim, M. A., Putra, P. A. A., \& Hidayat, Y. R. (2019, March). The Effectivity of Education Program of the Sharia Fund. In Social and Humaniora Research Symposium (SoRes 2018). Atlantis Press.

Wardhani, Intan Mahendrasari. 2010. "Evaluasi Program Community Development Mengentaskan Kemiskinan (CD-MK) di Kabupaten Bantul Tahun 2006-2009 (Study Kasus Desa Bangunharjo dan Desa Timbulharjo)", Skripsi tidak dipublikasikan, Universitas Muhammadiyah Yogyakarta. 